\title{
PREVENTION OF ELDER ABUSE IN DOMESTIC SETTING: ISLAMIC APPROACH
}

\author{
Asiah Bidin ${ }^{1}$ \\ Faculty of Law and International Relations, \\ Universiti Sultan Zainal Abidin (UniSZA), Malaysia \\ (Email: asiah@unisza.edu.my) \\ Noraida Harun ${ }^{2}$ \\ Faculty of Law and International Relations, \\ Universiti Sultan Zainal Abidin (UniSZA), Malaysia \\ (Email: noraida@unisza.edu.my) \\ Kamaliah Salleh ${ }^{3}$ \\ Faculty of Law and International Relations, \\ Universiti Sultan Zainal Abidin (UniSZA), Malaysia \\ (Email: kamaliahsalleh@unisza.edu.my) \\ Noor 'Ashikin Hamid ${ }^{4}$ \\ Faculty of Law and International Relations, \\ Universiti Sultan Zainal Abidin (UniSZA), Malaysia \\ (Email: shikin@unisza.edu.my)
}

Accepted date: $22-02-2019$

Published date: 10-07-2019

To cite this document: Bidin, A., Harun, N., Salleh, K., \& Hamid, N. A. (2019). Prevention of Elder Abuse in Domestic Setting: Islamic Approach. International Journal of Law, Government and Communication, 4(15), 91-100.

DOI: $10.35631 /$ ijlgc. 4150010

\begin{abstract}
Elder abuse is a malicious act prevalent in almost all over the world. In searching for solutions, many theories have been introduced and initiated. Despite numerous approaches and research carried out to find ways to prevent elder abuse case, only few studies have examined the prevention of elder abuse from an Islamic perspective. The aims of this article are to discuss the status of the elderly and the concept of family life in Islam. The article further explores the concept of prevention of elder abuse in domestic setting from an Islamic perspective. This article applies a qualitative approach. The verses from al-Quran and the Sunnah/ hadith of the Prophet (PBUH) were gathered and analysed using content analysis. Based on the analysis, this article found that Islam has laid down a very clear provisions pertaining to managing the family relationship by prescribing every individual member in a family the specific rights and obligations. The strict obedience and adherence to these provisions can prevent the problem of abuse of the elderly parents by family members.
\end{abstract}

Keywords: Abuse, Elderly, Islam, Rights, Prevention

\section{Introduction}

According to the World Ageing is an inevitable process. Most developed countries have accepted the chronological age of 65 years as a definition of elderly, but it does not fit well with some other countries. People worldwide are living longer. In 2050 the number of the 
older person aged 60 and above is expected to be 2.1 more than the population of adolescents and youth at ages 10 to 24 (United Nations, 2017). Nobody wants to spend his later life homeless, without income and savings, without proper access to food and cloth, sanitation, health or being a burden to his family. However, in contemporary society, these problems happen almost everywhere either in the developed or developing countries. Some older people especially the elderly parents who have frailty vulnerable in life have been subject to abuse by their family members. Literatures on the incidence of abuse on the elder people reveal that domestic elder abuse is prevalent in almost all over the world. It is a hidden and complex problem (Quinn \& Tomita, 1997) which is rarely exposed to the public. It is also a violation of human rights (World Health Organization, 2002). Several mechanisms have been put forward to address and cope with the problem of elder abuse. Some countries have introduced certain legal frameworks which provide remedies and impose penalties to the abuser. Creating community supports, services to the caregivers as well as the elderly people and training to people who involve in the care and of the elderly are among the initiatives taken to prevent the case of abuse. Despite numerous writings on the prevention of elder abuse, very little studies were conducted to look into the prevention of elder abuse from an Islamic perspective. This article discusses the status of the elderly and the concept of family life in Islam. It further explores the Islamic teachings on the rights and obligation of an individual in a family. As elder abuse in domestic setting occurs between family members, its prevention and solution must be done within the family structure itself. Adherence to the Islamic teachings on family management, rights and obligations in a family form the basis to prevent abuse cases in domestic setting.

\section{Literature Review}

There are five points will be discussed in literature review namely the definition and types of elder abuse, the position and rights of elderly in Islam, Islamic views on elder abuse and Islamic approach on the prevention of elder abuse.

\section{Definition of Elder Abuse}

According to the World Health Organization (2002), elder abuse refers to all types of mistreatment or abusive behaviours towards older adults. It can be an act of commission (abuse) or omission (neglect), intentional or unintentional and can take many forms including physical, psychological and sexual abuse, financial exploitation and neglect.

The literature shows that defining elder abuse or also termed as elder mistreatment orneglect is problematic and that the definitions vary internationally. The reason for this difficulty arises from the differences in theories about the nature and causes of abuse and neglect of older people (Lachs \& Pillemer, 2004). The American Medical Association's Guidelines on elder mistreatment defines elder abuse as "acts or commission or omission that result in harm or threatened harm to the health or welfare of an adult" (Jayawardena \& Liao, 2006.) Most writings in Malaysia use the definition developed by Action on Elder Abuse (AEA) which was adopted by the International Network for the Prevention of Elder Abuse (INPEA), that is "elder abuse is a single or repeated act or lack of appropriate action, occurring within any relationship where there is an expectation of trust which causes harm or distress to an older". (World Health Organization, 2006). Although this definition has been widely used, studies conducted in China (Hong Kong SAR), Finland, Greece, India, Ireland, Israel, Norway, Poland and South Africa have approached the topic in distinctly different ways (World Health Organization, 2006). 


\section{Types of Elder Abuse}

Elder abuse may be physical, sexual, psychological, or financial. It may be intentional, unintentional or the result of neglect. Elder abuse may cause harms to the older person either temporarily or over a period of time. Abuse occurs in many forms and a variety of settings. Physical abuse consists of intentional infliction of physical harm of an older person. The abuse can range from slapping an older adult to beatings to excessive forms of a physical restraint. Financial abuse or also known as material abuse happens when the family members misused, misappropriated or exploited older adults' possessions, property or monetary assets. Psychological or emotional abuse consists of the intentional infliction of mental harm or psychological distress upon the older adult. The abuse can range from insults and verbal assaults to threats of physical harm or isolation. When there is any sexual activity for which the older person does not consent or is incapable of giving consent, it is known as sexual abuse. The sexual activity can range from exhibitionism to fondling to oral, anal, or vaginal intercourse (American Psychological Association, 2012).

Another most common form of elder abuse is neglect where the caregiver fails to meet the physical, social or emotional needs of the older person. Neglect can be done passively or actively. The difference between active and passive neglect lies in the intent of the caregiver. For active neglect, the caregiver intentionally fails to meet his/her obligations towards the older person. On the other hand, passive neglect happens when the failure is unintentional but often the result of caregiver overload or lack of information concerning appropriate caregiving strategies.

Elder abuse can be committed either in domestic setting or in the institution. Domestic elder abuse refers to abuse by a family member or caregiver who is in the home. Institutional elder abuse on the other hand refers to abuse in residential facilities, such as nursing homes, where caregivers have a legal or contractual obligation to provide attention and protection.

Elder abuse and neglect take place at home as the great majority of older people live on their own or with their spouses, children, siblings or other relatives. When elder abuse happens at home, family, other household members or paid caregivers are usually the abusers. Occasionally, there are also reports of nursing home residents who have been mistreated by the staff. Even though such abuse does occur, institutional elder abuse is not the most common type of elder abuse compared to domestic elder abuse.

\section{The Position and Rights of the Elderly in Islam}

The status of elderly is very special in Islam. Islam gives them a high status before Allah, rights to be honoured and respected by other human fellows. As reported by At-Tirmidhi, Anas ibn Malik narrated that the Prophet (PBUH) said,

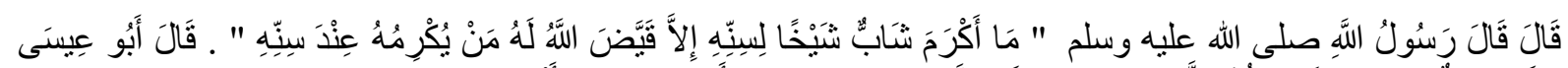

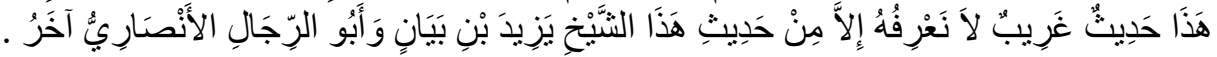

"If a young man honours an elderly on account of his age, Allah appoints someone to honour him in his old age."

Narrated from Ibn Abbas that The Prophet (PBUH) also used to say:

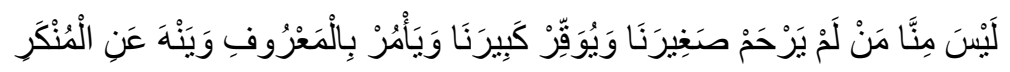


"He is not one of us who does not have mercy upon our young, respect our elders, and command good and forbid evil."

In another hadith, the Prophet said:

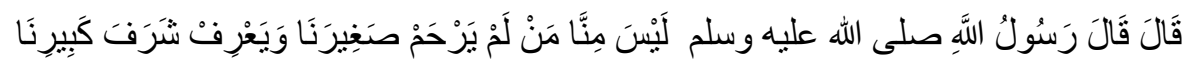

Amr bin Shu'aib narrated that his father, from his grandfather, who said that the Messenger of Allah said "He is not one of us who does not have mercy upon our young, nor knows the honor of our elders."

The above hadiths highlight the special position of the elderly in Islam, namely they possess the right to be respected and honoured by other people. Apart from that, Islam also provides the manner to deal with the older people. For example, if the younger people walk with the elderly, they are encouraged to walk after him or to his right. In having meals, the elderly are given priority to be served first and the younger people are taught not to take the food before the elderly do so.

Apart from the Sunnah of the Prophet (PBUH), Al-Quran has laid down very specific provisions that the elderly parents should be honoured, respected, dignified, right to be treated with kind treatment and rights for maintenance and care.

It is a blessing for a community to have the aged people because Allah gives privilege to them. Therefore, those who give a kind treatment to the elderly, they will be blessed by Allah (Jasmi \& Md Saleh @ Masrom (2007).

Islam requires the children to obey, give respect, honour and give kind treatment to their parents, regardless of their age. The parents have rights to be respected even though they are non-Muslim.

In Al Ahqaf [46:15], Allah says:

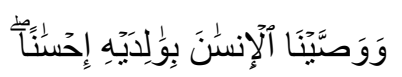

"And We have enjoined upon man, to his parents, good treatment."

Again, Allah says in Al'Ankabut [29:8]:

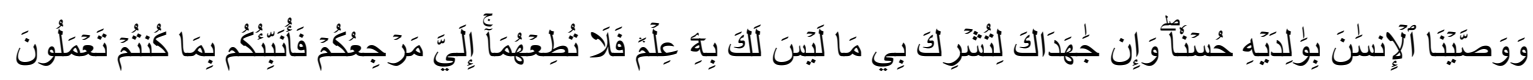

"And We have enjoined upon man goodness to parents. But if they endeavor to make you associate with Me that of which you have no knowledge, do not obey them. To Me is your return, and I will inform you about what you used to do."

In the above verses, Allah imposes the obligation to give a kind treatment to the parents in general. However, in another verse, Allah clearly mentions on the obligation of the children to respect and give a kind treatment to the elderly parents. Allah says in verse Al Isra' [17:2324]: 


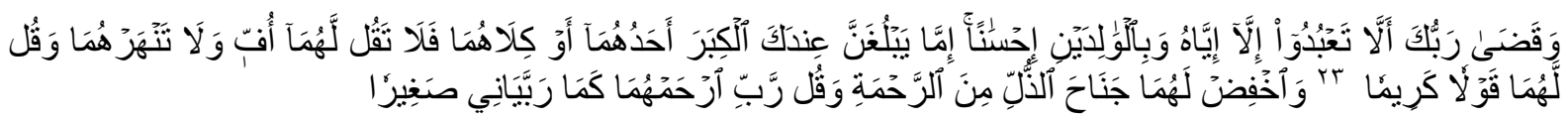

"And your Lord has decreed that you not worship except Him, and to parents, good treatment. Whether one or both of them reach old age [while] with you, say not to them [so much as], "uff," and do not repel them but speak to them a noble word ${ }^{(23)}$ And lower to them the wing of humility out of mercy and say, "My Lord, have mercy upon them as they brought me up [when I was] small." (24)

The verses clearly show that kindness towards parents is mentioned along with belief in One God. These verses reflect the compassion, respect and sense of responsibility that Islam requires the believers to have towards their parents. The verse then forbids the utterance of harsh words, admonish rudely or curse parents.

All the above provisions from the Quran clearly indicate the command from Allah for children to treat parent especially the elderly parents with a kind treatment. Even the utterance of the word "uff" also considered as a great sin, what more causing a physical harm or emotional distress to them.

Other than right to be respected, Islam required the children to provide for their parent's maintenance in their old age. Maintenance to parents includes food and care. Allah says in alQuran in Al Baqarah [2:215]:

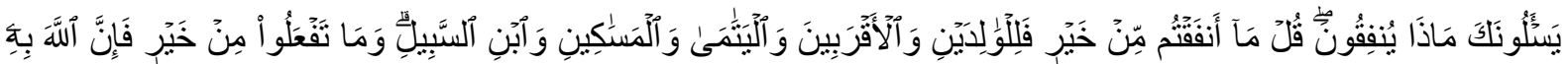
عَلْيخٍ

"They ask you, [O Muhammad], what they should spend. Say, "Whatever you spend of good is [to be] for parents and relatives and orphans and the needy and the traveler. And whatever you do of good - indeed, Allah is Knowing of it."

The duty of children to maintain parents can also be seen in the hadith narrated from Jabir bin Abdullah:

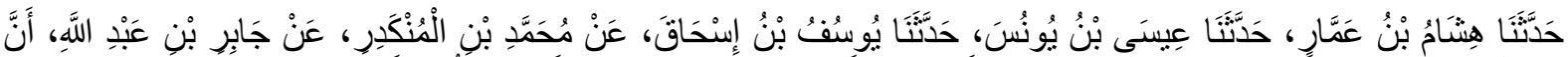

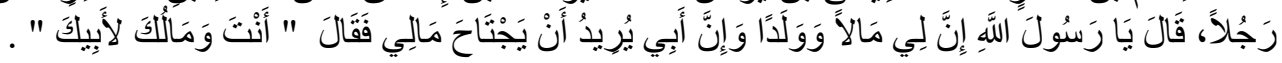

"A man came to the Prophet and said: My father is taking all my wealth. He said: "You and your wealth belong to your father". And the Prophet said: "Your children are among the best of your earnings, so eat from your wealth."

From this hadith, it can be concluded that parents are allowed to take a portion of their children's property to maintain themselves or as much as what is a necessity for them.

The above authorities from al-Quran and as Sunnah explain on the rights of the parents for maintenance from the children

\section{Islamic Views against Elder Abuse}

Islam, neither in Al-Quran nor the hadith of the Prophet (PBUH) prescribe a specific Islamic ruling $(\mathrm{hukm})$ on elder abuse. However, analysing the provisions in al Quran and hadiths relating to the rights of the elderly, the obligation on the part of the children to serve, obey 
and treat kindly the parents particularly elderly parents, it can be said that elder abuse is in fact a great sin. Allah says in verse Al Isra' [17:23-24]:

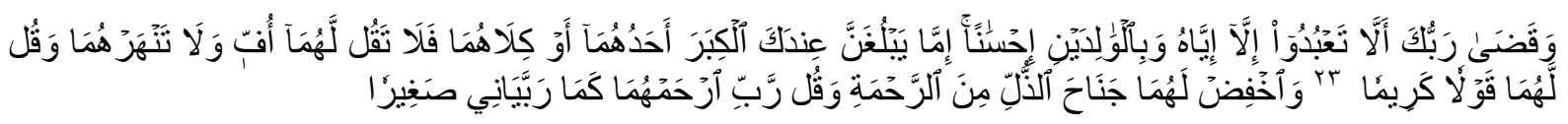

"And your Lord has decreed that you not worship except Him, and to parents, good treatment. Whether one or both of them reach old age [while] with you, say not to them [so much as], "uff," and do not repel them but speak to them a noble word ${ }^{(23)}$ And lower to them the wing of humility out of mercy and say, "My Lord, have mercy upon them as they brought me up [when I was] small."(24)

In explaining this verse, al-Qaradhawi (1995) said "If a lesser thing than saying "uff" to parent were known to Allah, He (Allah) would have prohibited (even that).

The above verse clearly forbids the utterance of harsh words, admonish rudely or curse parents. According to Islamic jurisprudence, the forbiddance of uttering harsh words that hurt the feelings of parents, specifically the utterance "uff" (the word of contempt), as mentioned in the above verse, is looked at from a general aspect. Applying the qiyas (method of analogy), the forbiddance encompasses all words and actions that could either physically hurt or emotionally abuse the parents. The point of similarity between words and actions is the reason or 'illah of the related rulings, which is to hurt the parents. Since words such as "uff" is seen as a minor act but the verdict is that is is prohibited, no doubt, committing more serious or severe acts such as cursing, admonishing rudely, using physical force, has a greater effect (major sin) (Zaydan, 2014).

\section{Islamic Approach in Preventing Elder Abuse}

As indicated by Karl \& Wolf (1986), elder abuse is a manifestation of a conflict in a family, it is felt that its solution should be done within the family structure itself. Islam is a unique religion. It is a way of life. Its teaching encompasses every aspect of the life of the universe, including human beings, animals and the environment. As for human being, no doubt, home plays a very important role. It is a place where an individual is born, brought up and trained in a family atmosphere. Human characters and habits are developed at home and in the family. These factors are responsible for his future attitude and career. This is the reason why al-Quran gives so much emphasis on family life and lays down guidance to mankind to maintain a good relationship in a family. A good family order serves as a model for the society and its people determine the future of a nation. From an Islamic perspective, a family is a divinely inspired institution (Dhami and Aziz, 2000). As the modern term, filial piety is used to refer to the practice of respecting and caring for parents in old age (Hashimoto \& Ikels, 2005), this concept has been greatly emphasized in al-Quran itself (Roberts, 1971).

In Islam, the concept of prevention of domestic elder abuse goes to the root of family life. Islam has determined the individual's role, rights and responsibilities in a family. A good family that follows Islamic teaching in its management is a basis for the family's strength. Islam prescribes provisions on how to manage the family, either in al-Quran or the Sunnah of His Prophet (PBUH). The management of a good family starts even before the formation of the family itself where the Prophet says that it is important to choose the prospective wife based on her religion, not solely based on her beauty or wealth or property. This is to make sure that the future family will be managed according to Islam. 


\section{Husband - Wife Relationship and their Rights and Obligations}

The main objective of marriage is to create a family which will live together honourably and harmoniously in love and affection so as to make home a place of peace. Husband and wife, particularly as father and mother, are the two significant organs in the family. It is important that their relationship should be cordial as well as harmonious to achieve happiness and prosperity. It will serve as a model and gives impact to others especially their children and younger generations to follow. Allah says in Ar Rum [30:21]:

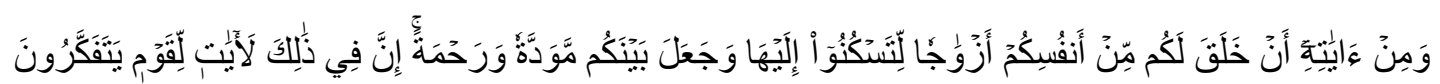

"And of His signs is that He created for you from yourselves mates that you may find tranquillity in them; and He placed between you affection and mercy. Indeed, in that are signs for a people who give thought."

Both the husband and wife should respect and be complementary to each other. The relationship between the two should be the most intimate. Al-Quran has so beautifully described the type of their homogeneity when it says that husband and wife are garments for each other. The husband should treat his wife with the best and kind treatment, provide her maintenance and proper care as prescribed by al-Quran, unless she is found guilty of open indecency. In this respect, the matter will be decided by the appropriate authority. Allah says in al-Baqarah [2:187]:

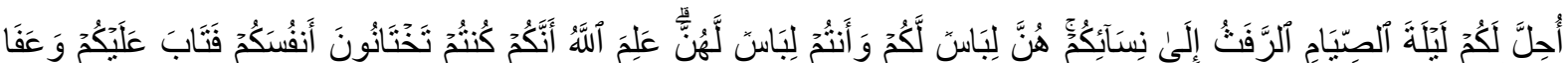

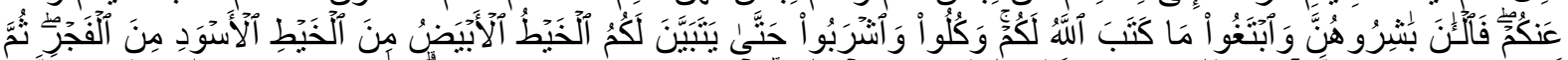

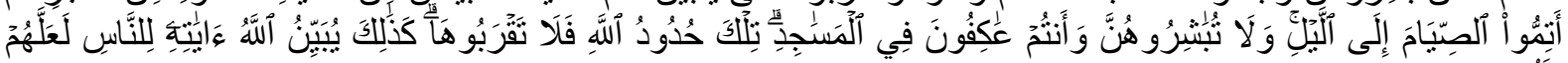

"It has been made permissible for you the night preceding fasting to go to your wives [for sexual relations]. They are clothing for you and you are clothing for them. Allah knows that you used to deceive yourselves, so He accepted your repentance and forgave you. So now, have relations with them and seek that which Allah has decreed for you. And eat and drink until the white thread of dawn becomes distinct to you from the black thread [of night]. Then complete the fast until the sunset. And do not have relations with them as long as you are staying for worship in the mosques. These are the limits [set by] Allah, so do not approach them. Thus, does Allah make clear His ordinances to the people that they may become righteous."

Allah further says in An Nisaa' [4:19].

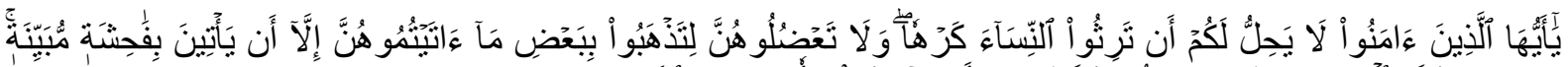

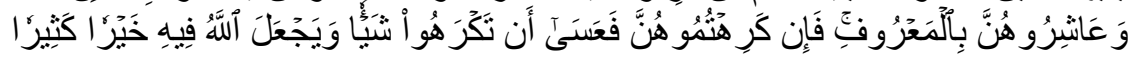

"O you who have believed, it is not lawful for you to inherit women by compulsion. And do not make difficulties for them in order to take [back] part of what you gave them unless they commit a clear immorality. And live with them in kindness. For if you dislike them - perhaps you dislike a thing and Allah makes therein much good."

From the above provisions, it is clear to show that both husband and wife are very important in the management of the family. The wife should be treated wisely. Islam encourages the couple to settle the dispute through amicable settlement. Islam allows both of them to 
separate in a good manner and with a proper procedure. Therefore, there is no room to see the case of abuse of the wife by the husband even until they reach the old age.

Within a family, the role of the father is very important as the entire responsibility of family management rests on him, particularly at the stage when children are in their tender age. Heavy responsibilities are burdened on the father. He has to protect himself as well as his family members from all kinds of troubles and difficulties. He has to arrange for their basic needs health, care and education. The father is required to give Islamic education to his children so that they can differentiate between good and wrong. Apart from teaching them, parents should also show a good example to their children (Yusoff, 2006). Being the head of the family, the father has to make sure that he has taught what is required by Islam. He has to show the correct path to his family to manage their life in this world and hereafter.

\section{Children-Parents Relationship}

Apart from the relationship between husband and wife, Islam also deals with the relationship between children and their parents. Islam places the parents in the highest position among human being. The recognition and respect of parents are mentioned several times in al-Quran Children should be good and faithful to parents. It is the right of parents to be treated with kindness, obeyed and honoured by their children. Children should avoid upsetting them and should seek their pleasure as much as possible. Pleasing parents is one of the most virtuous acts.

When parents become older, sometimes their attitude becomes abnormal. Their acts and behaviour become childish. At this moment, the children should not behave with them indifferently by banging, scolding, or giving erratic treatment. Instead, the children should help and look after them. The best possible treatment should be rendered to them (Al Ahqaf; 46:15)

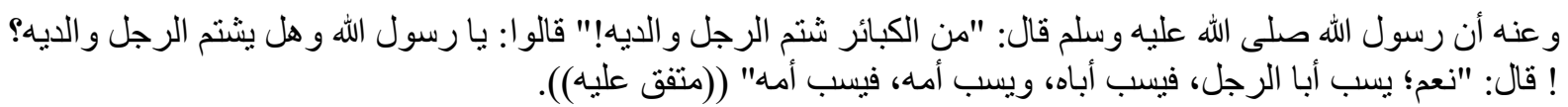

Abdullah bin 'Amr bin Al-'As (May Allah be pleased with them) reported that The Prohet (PBUH) said, "It is one of the gravest sins to abuse one's parents." It was asked (by the people): "O Messenger of Allah, can a man abuse his own parents?" The Prphet (PBUH) said, "He abuses the father of somebody who, in return, abuses the former's father; he then abuses the mother of somebody who, in return, abuses his mother".

The Prophet declared that the disobedience to parents is a major sin, second after ascribing partners to Allah. It was narrated by Abdullah bin 'Amir bin Al 'As that the Prphet (PBUH) said:

قال رسول الله صلى الله عليه وسلم: "ألا أنبئكم بأكبر الكبائر؟" ـثلاثًا قلنا: بلى يا رسول الله: قال: "الإشر الك بالله، وعقوق الو الدين، وقتل النفس، و اليمين الغموس ول

The Prophet said: "Shall I not inform you about the three major sins? Those who were present replied, Yes, O Messenger of Allah" He said "Associating partners with Allah and disobedience to parents, killing without justification and taking false testimony"

From the above explanation, it can be seen that Islam has laid down clear provisions on the position of the elderly in Islam. Islam honours the elderly by giving them special rights to be 
respected. Islam also provides clear provisions to every Muslim to manage the family by prescribing each and individual's rights and obligation. It cannot be denied that a good family will result in a good society. As the problem of domestic elder abuse happens in a family, where the victim is the elderly and the perpetrators are also among the family members, thus preventing it also should be done in the family.

\section{Conclusion}

In conclusion, it can be said that the incidence of elder abuse in domestic settings is a proof that there is a conflict in the family. In modern life, with the changes in the family structure such as from extended to a nuclear family or the problem in the extended family structure itself, the family ties become loosen and the social problem can occur even at home. Abuse of the elderly is one example of a social problem occurring within family members. Thus, its prevention should start from the family itself. In Islam, the family unit is regarded as a basis for a healthy and balanced society. Apart from age, the elderly especially elderly parents are respected due to their sacrifices, life experiences as well as their hierarchic position within the family unit. It is submitted that Islam has laid down very detail guidelines on the management of family affairs. Following those guidelines as stated in al-Quran or the hadith of the Prophet (PBUH), there might not have elder Muslims entering folk homes or being abused by their family members.

\section{References}

Al-Quran. https://quran.com/

American Psychological Association. (2012). Elder Abuse \& Neglect - In Search of Solutions. Washington DC: American Psychological Association.

Dhami, S and Aziz, S. (2000). The Muslim Family Predicament and Promise. West J Med. 173 (5), 352-356.

Hashimoto, A. \& Ikels, C. (2005). Filial Piety in Changing Asian Societies, in. Malcom L. Johnson, (ed). The Cambridge Handbook of Age and Aging. UK: Cambridge University Press.

Jasmi, K.A \& Md Saleh @ Masrom, S.F. (2007). Pendidikan dan Pembangunan Keluarga Cemerlang. Skudai: Penerbit Universiti Teknologi Malaysia.

Jayawardena, K.M \& Liao, S. (2006). Elder Abuse at End of Life. Journal of Palliative Medicine, 9 (1), 127-136.

Karl A. Pillemer and Rosalie S. Wolf (eds.). (1986). Elder Abuse: Conflict in the Family. Dover, MA: Auburn House.

Krug, E.G., Dahlberg, L.L., Mercy, J.A., Zwi, A, and Lazano, R. (ed.). (2002). World Report on Violence and Health. Geneva: World Health Organization.

Lachs, M. S. \& Pillemer, K. (2004). Elder Abuse. The Lancet, 364 (9441), 1263 - 1272.

Quinn, M. J. \& Tomita, S.K. (1997). Elder Abuse and Neglect. New York, US: Springer Publishing Company.

Roberts, R. (1971). The Social Laws of the Qoran. London: Curzon Press.

Sunnah.com. https://sunnah.com/

United Nations. (2017). World Population Ageing 2017 Highlights. 1-46. https://www.un.org/en/development/desa/population/publications/pdf/ageing/WPA20 17_Highlights.pdf.

World Health Organization. (2006). National Report on Violence and Health - Malaysia. http://s3.amazonaws.com/zanran_storage/www.who.or.jp/ContentPages/16320361.pf

Yusoff, I (2006). Pendidkan Asas Anak-anak di Rumah, in Ab. Rahman, M. @ I., Awang, J. \& Ismail, I. (ed), Agama dan Pembangunan Kontemporari. Kuala Terengganu: Yayasan Islam Terengganu. 
Zaydan, Abdul Karim. (2014). Al-Wajiz fi Usul al-Fiqh. Beirut: Muassasah al-Risalah Nashirun. 